Journal of Technology and Social for Community Service (JTSCS)

Vol. 2, No. 2, September 2021, page-page. 89 95

P-ISSN: 2723-455X

E-ISSN: 2723-2026

available online at: https://ejurnal.teknokrat.ac.id/index.php/teknoabdimas

\title{
ADVOKASI HUKUM HAK-HAK KEKAYAAN INTELEKTUAL BAGI SENIMAN TARI DI ASOSIASI SENI NUWO KONENG
}

\author{
Yunita Maya Putri ${ }^{1}$, Rehulina ${ }^{2}$, Tristyanto ${ }^{3}$, Amelia Hani Saputri ${ }^{4}$ \\ ${ }_{1,2,3,4}$ Universitas Lampung
}

Email : yunita.maya@fh.unila.ac.id ${ }^{1}$

\begin{tabular}{lll}
\hline Received: (29 Agustus 2021) & Accepted: (10 September 2021) & Published : (15 September 2021) \\
\hline
\end{tabular}

\begin{abstract}
This study aims to provide knowledge and understanding to dance artists in art associations regarding the legal protection of copyrighted works under the intellectual property rights regime, as well as copyrighted works that are categorized as personal and communal intellectual property as well as the moral and economic values that arise from these copyrighted works. Mitra are new dance artists who still do not understand how to protect copyrighted works. Limitations such as what is allowed or not a copyrighted work is recognized as a personal or communal intellectual copyright. The methods used are lectures (submission of material) and assistance in classifying copyrighted works that can be recognized and obtain copyright as well as compiling administrative requirements that must be met in managing copyright documents. Based on this, the service is carried out by several people who come from various fields of science such as law, dance education and computer science. The partner is the "Nuwo Koneng Production Art Association". This art association is a group of dance studios, dance creators, dancers, music creators and musicians based in Bandar Lampung. Established since 2019 and having its address in Bandar Lampung. The art workers consisting of musicians and dancers who are members of this association are 20 studios which are divided into several groups.
\end{abstract}

Keywords: Intellectual Property Rights, Copyrights, Dance Artists

\begin{abstract}
Abstrak
Penelitian ini bertujuan untuk memberikan pengetahuan dan pemahaman kepada seniman tari di asosiasi seni mengenai perlindungan hukum terhadap karya cipta dalam rezim hak kekayaan intelektual, serta karya cipta yang dikategorikan sebagai kekayaan intelektual personal dan komunal juga nilai moral dan ekonomis yang muncul dari karya cipta tersebut. Mitra merupakan para seniman tari baru yang masih belum memahami bagaimana perlindungan terhadap karya cipta. Batasan seperti apa yang diperbolehkan atau tidak sebuah karya cipta tersebut diakui sebagai karya cipta intelektual personal maupun komunal. Metode yang digunakan adalah ceramah (penyampaian materi) dan pendampingan dalam mengklasifikasi karya cipta yang bisa diakui dan mendapatkan hak cipta serta menyusun syarat administratif yang harus dipenuhi dalam mengurus dokumen hak cipta. Berdasarkan hal tersebut maka pengabdian dilakukan oleh beberapa orang yang berasal dari berbagai bidang ilmu seperti hukum, pendidikan tari dan ilmu komputer. Mitra adalah "Asosiasi Seni Nuwo Koneng Production". Asosiasi seni ini merupakan kelompok-kelompok sanggar tari, pencipta tari, penari, pencipta musik dan pemusik yang berada di Bandar Lampung. Berdiri sejak tahun 2019 dan beralamat di Bandar Lampung. Para pekerja seni yang terdiri dari pemusik dan penari yang tergabung dalam asosiasi ini berjumlah 20 sanggar yang terbagi kedalam beberapa kelompok.
\end{abstract}

Kata Kunci: Hak Kekayaan Intelektual, Hak Cipta, Seniman Tari

\section{To cite this article:}

Yunita Maya Putri, Rehulina, Tristyanto, Amelia Hani Saputri. (2021). ADVOKASI HUKUM HAK-HAK KEKAYAAN INTELEKTUAL BAGI SENIMAN TARI DI ASOSIASI SENI NUWO KONENG. Journal of Technology and Social for Community Service (JTSCS), $\operatorname{Vol}(1), 89-95$. 


\section{PENDAHULUAN \\ Analisis Situasi}

Negara memajukan kebudayaan nasional Indonesia di tengah peradaban dunia dengan menjamin kebebasan masyarakat dalam memelihara dan mengembangkan nilai-nilai budayanya Setiap manusia memiliki akal budi dan pikiran yang mampu menciptakan ilmu pengetahuan, teknologi dan karya seni, dimana hasil ciptaan atas karya seni tersebut harus dihormati dan dihargai sebagai suatu karya cipta yang merupakan ekspresi dari kemampuan berkarya si pencipta tersebut. Dalam perkembangannya, karya cipta hasil kreasi seorang manusia atau sekelompok orang yang telah menciptakan karya seni tersebut harus dilindungi dan memiliki hak cipta atas karyanya sehingga dapat memberikan kehidupan yang layak bagi si pencipta karya seni tersebut.

Di dalam Undang-undang Hak Cipta, dijelaskan bahwa "Negara memegang Hak Cipta atas folklore dan hasil kebudayaan rakyat yang menjadi milik bersama, seperti cerita, hikayat, dongeng, legenda, babad, lagu, kerajinan tangan, koreografi, tarian, kaligrafi, dan karya seni lainnya". Selanjutnya dijelaskan bahwa yang dimaksud dengan folklore dan ekspresi budaya tradisional adalah sekumpulan ciptaan tradisional, baik yang dibuat oleh kelompok maupun perorangan dalam masyarakat, yang menunjukkan identitas sosial dan budayanya berdasarkan standar dan nilai-nilai yang diucapkan atau diikuti secara turun temurun termasuk hasil seni antara lain berupa: lukisan, gambar, ukir-ukiran, pahatan, mosaik, perhiasan, kerajinan tangan, pakaian, instrumen musik dan tenun tradisional

Seni tari dan musik tradisional merupakan warisan budaya dari leluhur yang diturunkan dari generasi ke generasi berikutnya, bernilai dan memiliki daya guna yang tinggi, oleh karenanya sangat penting untuk dilindungi. Seni tari dan musik tradisional sebagai ekspresi budaya tradisional dilindungi berdasarkan Pasal 38 UndangUndang Hak Cipta tahun 2014. Dalam implementasinya, ketentuan ini belum terlaksana secara efektif. Salah satu faktor penyebabnya adalah masyarakat baru sebatas mengetahui, namun belum memahami substansinya, bahkan masih ada pekerja seni yang tidak mengetahui peraturan perundang-undangan tentang hak cipta terutama yang berkaitan dengan hak cipta akan kekayaan ekspresi budaya tradisional, termasuk pemahaman tentang pentingnya melakukan inventarisasi dan dokumentasi dalam rangka perlindungan hukum melalui kerjasama pemerintah dengan masyarakat serta pihak terkait. Selain itu pula hal yang lebih penting lagi dari keterkaitan antara hak cipta dan ekspresi budaya tradisional adalah bahwa karya cipta seni yang dihasilkan oleh perorangan merujuk kepada budaya-budaya tradisional yang dihasilkan oleh masyarakat terdahulu dimana budaya tradisional tersebut menjadi budaya bersama masyarakat suatu daerah. Hal ini banyak terjadi pada tari-tarian dan musik tradisional.

Ketidaktahuan bahkan ketidakpedulian akan pentingnya menjaga hasil karya cipta dan kreatifitas dari pekerja seni ini akan mengakibatkan kerugian baik materill maupun immateriil bagi mereka. Karena, hal tersebut dapat dimanfaatkan oleh pihak lain untuk mengambil dan mengakui karya-karya mereka, oleh karena karya tersebut akan menghasilkan nilai ekonomi dan nilai perkembangan budaya bagi negara-negaranya. Seperti yang telah dilakukan oleh Malaysia dengan mengakui Tari Pendet, Wayang dan Reog Ponorogo. Untuk itu kita sebagai warga negara mempunyai hak dan kewajiban dalam melindungi warisan-warisan budaya Indonesia yang telah lama tersimpan secara turun temurun serta mengembangkan warisan-warisan budaya yang ada dengan menciptakan hasil karya dan kreatifitas yang baru dengan memahami perlindungan hukum terhadap hasil cipta dan karya. Pengembangan budaya melalui karya cipta dan kreatifitas tersebut berasal dan dimulai dari karya cipta budaya yang ada di masing-masing daerah. Salah satu daerah yang memiliki kekayaan budaya tari dan musik tradisional adalah Provinsi Lampung. Perkembangan seni tari dan musik di Lampung sendiri sudah sangat berkembang dengan pesat sehingga sangat penting sekali bagi pekerja seni untuk mendapatkan pengetahuan dan pemahaman mengenai hak cipta ekspresi budaya tradisional ini terhadap karya-karyanya. Sehingga selain hak cipta akan karya terlindungi dan hal tersebut menjadi bagian dari pengembangan ekonomi budaya serta masyarakat di era saat ini.

Salah satu mitra yang menjadi sasaran untuk dapat meningkatkan perlindungan hasil karya ciptanya adalah "Asosiasi Seni Nuwo Koneng Production". Asosiasi seni ini merupakan kelompok-kelompok sanggar tari, pencipta tari, penari, pencipta musik dan pemusik yang berada di Bandar Lampung. Berdiri sejak tahun 2019 dan didirikan oleh Sandika Ali yaitu seorang pemilik sanggar tari dan juga penari, sanggar ini beralamat di jl. Rusa Sukamenanti Bandar Lampung. Para seniman tari yang terdiri dari pemusik dan penari yang tergabung dalam sanggar ini berjumlah 20 sanggar yang terbagi kedalam beberapa kelompok. Sebelum merencanakan pengabdian ini, ketua pengabdian sudah lebih dulu melakukan kegiatan pengabdian lewat sosialisasi perlindungan hukum bagi hak cipta tari di sebuah sanggar tari dan musik. Kegiatan tersebut mendapatkan respon yang antusias dan sangat baik dari para pekerja seni yang kebanyakan tidak memahami hak cipta dan hak cipta komunal, sehingga dengan rencana kegiatan ini akan menambah cakupan sasaran yang lebih luas dan ilmu yang lebih dalam 


\section{TELAAH PUSTAKA}

Perlindungan Hukum adalah memberikan pengayoman kepada hak asasi manusia yang dirugikan orang lain dan perlindungan tersebut diberikan kepada masyarakat agar mereka dapat menikmati semua hak-hak yang diberikan oleh hukum. Philipus M. Hadjon berpendapat bahwa Perlindungan Hukum adalah perlindungan akan harkat dan martabat, serta pengakuan terhadap hak-hak asasi manusia yang dimiliki oleh subyek hukum berdasarkan ketentuan hukum dari kesewenangan. Selanjutnya CST Kansil mengatakan bahwa Perlindungan Hukum adalah berbagai upaya hukum yang harus diberikan oleh aparat penegak hukum untuk memberikan rasa aman, baik secara pikiran maupun fisik dari gangguan dan berbagai ancaman dari pihak manapun. Dalam menjalankan dan memberikan perlindungan hukum dibutuhkannya suatu tempat atau wadah dalam pelaksanaannya yang sering di sebut dengan sarana perlindungan hukum, sarana perlindungan hukum dibagi menjadi dua macam yang dapat dipahami, yaitu perlindungan hukum secara preventif dan perlindungan hukum secara represif.

Masyarakat mengharapkan adanya kepastian hukum karena dengan adanya kepastian hukum masyarakat akan tertib, aman dan damai. Masyarakat mengharapkan manfaat dalam pelaksanaan penegakkan hukum adalah untuk manusia maka pelaksanaan hukum harus memberi manfaat, kegunaan bagi masyarakat jangan sampai hukum dilaksanakan menimbulkan keresahan di dalam masyarakat. Masyarakat yang mendapatkan perlakuan yang baik dan benar akan mewujudkan keadaan yang tentram. Hukum dapat melindungi hak dan kewajiban setiap individu dalam kenyataan yang senyatanya, dengan perlindungan hukum yang kokoh akan terwujud tujuan hukum secara umum: ketertiban, keamanan, ketentraman, kesejahteraan, kedamaian, kebenaran, dan keadilan. Dengan demikian, kepastian hukum mengandung dua pengertian, yaitu pertama, adanya aturan yang bersifat umum membuat individu mengetahui perbuatan apa yang boleh atau tidak boleh dilakukan dan dua, berupa keamanan hukum bagi individu dari kesewenangan pemerintah karena dengan adanya aturan yang bersifat umum itu individu dapat mengetahui apa saja yang boleh dibebankan atau dilakukan oleh Negara terhadap individu.

HKI merupakan hak yang berasal dari karya, karsa, dan daya cipta kemampuan intelektualitas manusia yang memiliki manfaat serta berguna dalam menunjang kehidupan manusia dan mempunyai nilai ekonomi. Bentuk nyata dari hasil karya, karsa, dan daya cipta intelektualitas manusia tersebut dapat berupa ilmu pengetahuan, teknologi, seni dan sastra. Karya-karya tersebut dilahirkan atau dihasilkan atas kemampuan intelektual manusia melalui curahan waktu, tenaga, pikiran, daya cipta, rasa dan karsanya. Hal tersebut yang membedakan kekayaan intelektual dengan jenis kekayaan lain yang juga dapat dimiliki oleh manusia tetapi tidak dihasilkan oleh intelektualitas manusia. Karya-karya yang dilahirkan atau dihasilkan atas kemampuan intelektual manusia baik melalui curahan tenaga, pikiran dan daya cipta, rasa serta karsanya sudah sewajarnya diamankan dengan menumbuhkembangkan sistem perlindungan hukum atas kekayaan tersebut yang dikenal sebagai sistem Hak Kekayaan Intelektual (HKI).

Adapun tujuan perlindungan kekayaan intelektual melalui HKI secara umum meliputi:

a. Memberi kejelasan hukum mengenai hubungan antara kekayaan dengan inventor, pencipta, desainer, pemilik, pemakai, perantara yang menggunakannya, wilayah kerja pemanfaatannya dan yang menerima akibat pemanfaatan HKI untuk jangka waktu tertentu;

b. Memberikan penghargaan atas suatu keberhasilan dari usaha atau upaya menciptakan suatu karya intelektual;

c. Mempromosikan publikasi invensi atau ciptaan dalam bentuk dokumen HKI yang terbuka bagi masyarakat;

d. Merangsang terciptanya upaya alih informasi melalui kekayaan intelektual serta alih teknologi melalui paten;

e. Memberikan perlindungan terhadap kemungkinan ditiru karena adanya jaminan dari negara bahwa pelaksanaan karya intelektual hanya diberikan kepada yang berhak.

\section{METODE PELAKSANAAN}

Metode yang digunakan pada proses ini adalah ceramah (penyampaian materi) yang diikuti oleh seluruh mitra yang merupakan seniman tari dalam bidang musik dan tari yang tergabung dalam asosiasi seni. Sedangkan untuk proses pendampingan, metode yang digunakan adalah mengklasifikasi karya cipta yang bisa diakui dan 
mendapatkan hak cipta serta menyusun syarat administratif yang harus dipenuhi dalam mengurus dokumen hak cipta. Kegiatan yang akan dilakukan adalah:

1. Berkoordinasi dengan pihak mitra untuk mengadakan pertemuan dalam rangka penyampaian materi.

2. Mempersiapkan dokumen administratif untuk melaksanakan kegiatan termasuk tempat pelaksanaan dan segala hal yang dibutuhkan selama proses berlangsung.

3. Mengadakan pertemuan untuk menyampaikan materi terkait perlindungan hukum bagi karya cipta.

4. Melakukan proses pendampingan dalam pengklasifikasian dan persiapan pembuatan dokumen hak cipta yang diinginkan oleh mitra.

Keberadaan para seniman tari sebagai mitra dalam pelaksanaan kegiatan ini sangat penting, karena hasil dari kegiatan ini akan memberikan dampak terhadap pengetahuan yang akan mereka dapatkan sebagai pencipta karya seni dan budaya. Mengembangkan pola pikir mereka terhadap keberlangsungan suatu karya cipta yang akan meningkatkan pembangunan ekonomi masyarakat, kemajuan Provinsi Lampung serta perkembangan negara Indonesia di mata dunia.

Rancangan evaluasi dalam kegiatan ini dibedakan menjadi 2 (dua) macam, yaitu:

1. Evaluasi Perubahan pengetahuan yaitu Evaluasi ini dilakukan dengan pre test dan post test. Selisih antara pre test dan post test dinyatakan dalam bentuk persentase. Pertambahan tersebut kemudian dikelompokan dalam strata paham dan tidak paham.

2. Evaluasi Dampak yaitu Evaluasi ini dilakukan sebelum kegiatan berakhir. Mekanismenya dengan memberikan tugas sesuai dengan substansi kegiatan di lapangan dan menghitung berapa orang peserta yang dapat menerapkan pengetahuan yang telah mereka terima.

Selanjutnya kelanjutan dari program ini adalah pelaksana dapat bekerjasama dengan para seniman tari (mitra) lainnya dalam memberikan pengetahuan dan pemahaman perlindungan hukum bagi karya cipta seni dan budaya khususnya di Provinsi Lampung.

\section{HASIL DAN PEMBAHASAN Pelaksanaan Kegiatan}

Kegiatan pengabdian ini dilakukan pada hari kamis tanggal 3 agustus 2021 pukul 09.00 wib sampai dengan selesai. Bertempat di Dewan kesenian Lampung yang beralamat Pasar Seni Pusat kegiatan olah raga (PKOR) Bandar Lampung. Kegiatan ini diikuti oleh 35 peserta yang terdiri dari ketua asosiasi seni, penari dan pemain musik khususnya musik tradisional. Diawal pelaksanaan kami memperkenalkan anggota tim pengabdian beserta maksud dan tujuan dari pelaksanaan kegiatan pengabdian ini. Dikarenakan acara ini dilaksanakan pada saat era ppkm covid19 maka dari itu kami melaksanakannya dengan tetap memperhatikan protokol kesehatan covid19 dengan pengukuran suhu tubuh peserta dan juga mencuci tangan sebelum masuk ke ruangan. Untuk ruangan sendiri yang dipergunakan adalah ruang terbuka untuk berlatih menari dan bermain musik.

\section{Pemberian Materi}

Diskusi berfokus pada menghubungkan data dan hasil analisisnya dengan masalah atau tujuan kegiatan pengabdian kepada masyarakat dan konteks teoritis yang lebih luas. Dapat juga dibahas adalah jawaban atas pertanyaan mengapa fakta ditemukan dalam data. Diskusi ditulis terlampir pada data yang dibahas. Pembahasan diupayakan tidak lepas dari data yang dibahas. Hasil dan Diskusi memiliki proporsi sekitar 60-70\% dari naskah. Bagian ini adalah bagian utama dari artikel pengabdian kepada masyarakat. Hasil harus merangkum atau menyoroti temuan daripada memberikan hasil kegiatan pengabdian kepada masyarakat yang terperinci. Hasil juga berisi hasil yang diambil dari analisis data dan / atau hasil uji hipotesis dan hanya menyediakan data yang mendukung diskusi. Bagian ini termasuk tabel dan grafik yang diambil dari data hasil kegiatan pengabdian kepada masyarakat. 
Pemberian materi diawali dengan memberikan pertanyaan kepada para peserta terkait sejauh mana pemahaman mereka terhadap hak cipta, yaitu apa yang dimaksud dengan hak cipta dan hal-hal apa saja yang boleh diakui sebagai karya cipta. Selanjutnya materi dimulai dengan penjelasan mengenai perbedaan bentuk kepemilikan kekayaan intelektual yang terbagi menjadi 2 (dua) macam yaitu kepemilikan komunal dan kepemilikan personal. Kepemilikan komunal terbagi menjadi 4 (empat) bagian yaitu ekspresi budaya tradisional/folklore, pengetahuan tradisional, sumber daya genetik dan indikasi geografis. Sementara kepemilikan personal terbagi menjadi 7 (tujuh) yaitu hak cipta, hak paten, hak merek, desain industri, rahasia dagang, DTLST dan PVT. Hak cipta sendiri diatur dalam Undang-undang nomor 28 tahun 2014 namun untuk hak komunal belum diatur dalm undang-undang khusus atau tersendiri melainkan masih diatur bersama dalam undang-undang hak cipta.

Hak Cipta adalah hak eksklusif pencipta yang timbul secara otomatis berdasarkan prinsip deklaratif setelah suatu ciptaan diwujudkan dalam bentuk nyata tanpa mengurangi pembatasan sesuai dengan ketentuan peraturan perundang-undangan. Ciptaan yang dapat dilindungi, yaitu Buku, program komputer, pamflet, perwajahan (layout) karya tulis yang diterbitkan, dan semua hasil karya tulis lain; Ceramah, kuliah, pidato, dan ciptaan lain yang sejenis dengan itu; Alat peraga yang dibuat untuk kepentingan pendidikan dan ilmu pengetahuan; Lagu atau musik dengan atau tanpa teks; Drama atau drama musikal, tari, koreografi, pewayangan, dan pantomim; Seni rupa dalam segala bentuk seperti seni lukis, gambar, seni ukir, seni kaligrafi, seni pahat, seni patung, kolase, dan seni terapan; Arsitektur; Peta; Seni Batik; Fotografi; Terjemahan, tafsir, saduran, bunga rampai, dan karya lain dari hasil pengalihwujudan. Masa Pelindungan Ciptaan

- Perlindungan Hak Cipta : Seumur Hidup Pencipta + 70 Tahun

- $\quad$ Program Komputer : 50 tahun Sejak pertama kali dipublikasikan.

- Pelaku : 50 tahun sejak pertama kali di pertunjukkan.

- $\quad$ Produser Rekaman : 50 tahun sejak Ciptaan di fiksasikan.

- Lembaga Penyiaran : 20 tahun sejak pertama kali disiarkan.

Ketika berbicara mengenai unsur seni dan budaya khususnya tarian tradisional maka tidak terlepas dari kedua bagian penting dari kekayaan intelektual komunal maupun personal. Karena undang-undang hak cipta mengatur dan mensyaratkan batasan karya yang bisa diakui sebagai karya pribadi atau mengadopsi dari karya terdahulu yang dikenal sebagai milik masyarakat suatu daerah sehingga tidak bisa diakui sebagai hak cipta personal. Berkaitan dengan kekayan intelektual komunal sendiri pemerintah melakukan perlindungan defensif terhadap karya-karya seni cipta masyarakat tradisional selain itu pemerintah juga membangun pusat data KIK (kekayaan intelektual komunal). Inventarisasi dilakukan antara pemerintah pusat dan pemerintah daerah melalui studi lapangan (kelayakan), kelengkapan administrasi, pengusulan penetapan hasil inventarisasi dan atau pertukaran data.Selain memberikan materi kami juga meminta peserta untuk mempertunjukan karya cipta tari dan musik yang mereka buat dan tarian tradisional masyarakat lampung untuk dapat secara langsung melihat produk tarian (gerak tari) yang sama dan berbeda antar keduanya. Sehingga peserta langsung dapat memahami penjelasan dari materi yang telah diberikan. Selain itu dilanjutkan dengan sesi tanya jawab anatara peserta dan pemberi materi.

\section{Prosedur Hak Cipta}




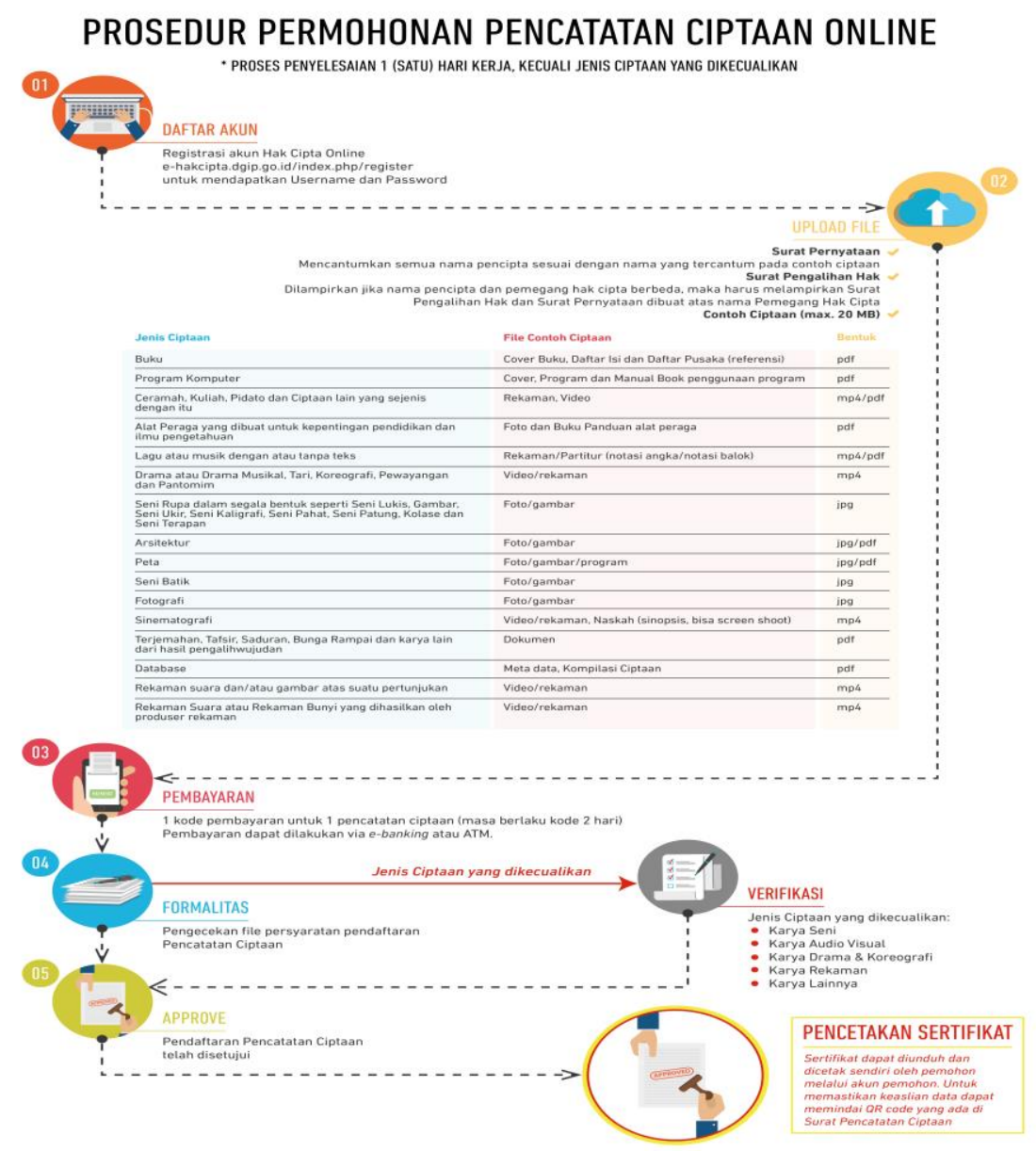

a. Prosedur permohonan hak cipta dapat dilakukan secara online melalui https://dgip.go.id/. Prosedur diawal dari pendaftaran akun, dilanjutkan upload file, pembayaran, formalitas, verifikasi, persetujuan, sampai pencetakan sertifikat.

b. Syarat Pendaftaran Hak Cipta

Beberapa syarat umum yang harus dilengkapi saat melakukan pendaftaran:

1. Nama, status kewarganegaraan, dan alamat lengkap pendaftar

2. Nama, status kewarganegaraan, dan alamat lengkap pemegang hak cipta

3. Judul karya

4. Waktu dan lokasi karya diumumkan untuk pertama kali

5. Uraian karya secara singkat

6. Sample karya yang didaftarkan

c. Dokumen yang Harus dilengkapi

Untuk mendaftarkan hak cipta atas nama perorang, Anda perlu melengkapi dokumen-dokumen yang terdiri atas:

1. Surat kuasa ditandatangani di atas materai 6000

2. Surat pernyataan keaslian karya

3. NPWP

4. Sample karya

Apabila ingin mendaftarkan hak cipta atas nama perusahaan, berikut adalah beberapa dokumen tambahan yang harus dilengkapi:

1. Surat pengalihan (dari pembuat karya kepada pemegang hak cipta) 
2. NPWP perusahaan

3. Akta perusahaan

4. Fotokopi identitas (KTP) pemohon dan pencipta karya

\section{KESIMPULAN}

Mayoritas Pekerja seni belum banyak mengetahui dan memahami persoalan kekayaan intelektual terlebih lagi kekayaan komunal. Tidak banyak juga yang mengetahui tentang hak cipta baik itu berkenaan dengan hal apa saja yang masuk kedalam hak cipta dan boleh diakui sebagai hak cipta ,peraturan perundang-undangan dan bagaimana cara mendaftarkan hak cipta. Selama ini pekerja seni hanya membuat karya lalu ditampilkan dihadapan umum dan selesai begitu saja setelah ditampilkan. Hampir setiap pekerja seni akan membuat karya-karya mereka yang baru apabila karya tersebut baru sekali atau dua kali ditampilkan. Jadi bisa dibayangkan begitu banyak karya yang mereka buat tetapi tidak didaftarkan sebagai hak cipta. Melalui kegiatan pengabdian ini banyak membantu pekerja seni memahami hal-hal yang berkaitan dengan hak cipta dan membangun pola pikir mereka untuk dapat membuat hak cipta bagi karya cipta mereka sendiri agar terlindungi dari pembajakan oleh orang lain.

\section{REFERENSI/DAFTAR PUSTAKA}

Badan Penelitian dan Pengembangan HAM Kementerian Hukum dan HAM RI 2014.

Peter Mahmud Marzuki. 2008. Pengantar Ilmu Hukum. Jakarta: Kencana.

Philipus M. Hadjon. 1987. Perlindungan Bagi Rakyat diIndonesia. Surabaya: PT.Bina Ilmu.

Soerjono Soekanto. 1984. Pengantar Penelitian Hukum. Jakarta: UI Press.

Undang-Undang Dasar 1945

Undang-Undang tentang Hak Cipta 